\title{
Sea-Level Rise and Coastal Inundation: A Case Study of the Gulf Coast Energy Infrastructure
}

\author{
David E. Dismukes, Siddhartha Narra \\ Center for Energy Studies, Louisiana State University, Baton Rouge, LA, USA \\ Email: dismukes@lsu.edu
}

How to cite this paper: Dismukes, D.E. and Narra, S. (2018) Sea-Level Rise and Coastal Inundation: A Case Study of the Gulf Coast Energy Infrastructure. Natural Resources, 9, 150-174.

https://doi.org/10.4236/nr.2018.94010

Received: March 1, 2018

Accepted: April 25, 2018

Published: April 28, 2018

Copyright (ㅇ 2018 by authors and Scientific Research Publishing Inc. This work is licensed under the Creative Commons Attribution International License (CC BY 4.0).

http://creativecommons.org/licenses/by/4.0/

\begin{abstract}
The United States (U.S.) Gulf Coast is a prominent global energy hub with a set of highly integrated critical energy infrastructure that rivals, if not surpasses, any comparable set of infrastructure anywhere in the world. Past extreme weather events in the region have led to critical energy infrastructure disruptions with national and global implications. Future sea-level rise (SLR), coupled with other natural hazards, will lead to a significant increase in energy infrastructure damage exposure. This research assesses coastal energy infrastructure that is at risk from various fixed SLR outcomes and scenarios. The results indicate that natural gas processing plants that treat and process natural gas before moving it into the interstate natural gas transmission system may be particularly vulnerable to inundation than other forms of critical energy infrastructure. Under certain SLR assumptions, as much as six Bcfd (eight percent of all U.S. natural gas processing capacity) could be inundated. More extreme SLR exposure assumptions result in greater levels of energy infrastructure capacity exposure including as much as 39 percent of all U.S. refining capacity based on current operating levels. This research and its results show that while fossil fuel industries are often referenced as part of the climate change problem, these industries will likely be more than proportionally exposed to the negative impacts of various climate change outcomes relative to other industrial sectors of the U.S. economy. This has important implications for the U.S. and global energy supplies and costs, as well as for the U.S. regional economies reliant on coastal energy infrastructure and its supporting industries.
\end{abstract}

\section{Keywords}

Gulf Coast, Energy Infrastructure, Sea-Level Rise, Climate Change, Natural Gas Processing, Refining, Power Generation 


\section{Introduction}

The exact amount of future sea level rise (SLR) is uncertain [1] [2], but the scientific community is reasonably certain that SLR and its acceleration, in conjunction with other natural hazards, will pose increasing challenges to coastal communities and infrastructure. Current sea levels do not pose an immediate threat to the coastal energy infrastructure as they are located at slightly higher elevation than normal sea levels, but the storm surges and flooding from extreme weather-related events often increase the current exposure of these facilities to near-term damage [3]. SLR is expected to lead to an increase in storm frequency and intensity. This will likely result in an increase in damage exposure for a wide range of critical energy infrastructure that includes natural gas and crude oil pipelines, petrochemical facilities, natural gas processing facilities, crude oil refineries, fractionation units, among others. These facilities cannot be simply shut-down and moved to avoid SLR damage exposure since they are long-lived with, in most instances, a considerable amount of remaining economic life. Understanding how these facilities will be impacted by future SLR requires a comparison of current facility characteristics and how those compare to SLR projections and scenarios. A scenario-based analysis of rising sea levels involves an understanding of coastal zone changes attributed to increased inundation extent, and frequent and longer duration coastal flooding at local scales.

SLR can have broad impacts on energy systems affecting a number of sectors [4] with cascading effects on the economy and environmental systems [5]. Storm surge and other forms of inundation during the U.S. 2004-2005 tropical season, coupled with later 2017 events such as Hurricane Harvey and Irma, underscore how a concentrated amount of critical energy infrastructure, located across a relatively geographically limited area, can have national and even global ramifications.

These very limited past experiences bode ill for the future of a large amount of Gulf Coast energy infrastructure. Considering the number of major flood events, comparable to the events like Hurricane Harvey, it is expected to increase since the annual likelihood of area-integrated precipitation in excess of $50 \mathrm{~cm}$ is also forecast to increase by as much as 18 percent during the $2081-2100$ period. This is significantly higher than the one percent probability seen for similar events during the 1981-2000 period [6]. SLR and concomitant nature-induced hazards demonstrate the need for quantitative risk assessments of such disasters across a range of industries and regions. However, risk assessment using current tools may prove to be inadequate since these traditional risk assessment models do not incorporate changes in hazard occurrences and strength [7].

The U.S. Gulf Coast has one of the most developed, and comprehensive energy economies in the world. This extensive energy economy is supported by a vast network of highly integrated infrastructure that is located in what experts and laypersons would appreciate as being "harsh". Extreme temperatures, high 
humidity, a relative low-elevation, and exposure to considerable tropical storm activity are everyday events. The region's changing ecosystem serves as a constant threat to this critical energy infrastructure and the resources it distributes across the U.S. and the globe [8] [9] [10] [11].

While some past academic research has recognized and explored the relationship of energy infrastructure and its environment [3] [12] [13] [14] [15] [16]; including industrial plant vulnerability to floods [17], production effects because of extreme weather events [18], and local-level impacts of tsunamis on refineries [19]; there is little analysis on the relationship between future SLR on coastal energy infrastructure in a concentrated area like the Gulf Coast.

The objectives of this research are to address this relationship through: (1) a review of historical SLR and regional variations across the Gulf Coast; (2) analysis of the direct impacts that SLR will likely have on specific energy system assets; and (3) examining adaptation methods, and the limitation to these methods and opportunities for future research.

\section{Background}

\subsection{SLR Projections and Scenarios}

Over the past several years, there has been a systematic increase in the use of SLR projections for decision making and policy planning. The use of future SLR projections is a critical first step in assessing critical energy infrastructure damage exposure. Tide gauges that provide records of historical SLR levels that span over several decades have been traditionally used to estimate future trends. Global SLR averaged $1.7 \pm 0.2 \mathrm{~mm} / \mathrm{yr}$ from the start of the 20th century [20], and with the potential for acceleration, SLR is expected to increase beyond the higher limit of $98 \mathrm{~cm}$ by 2100 as reported in the Intergovernmental Panel on Climate Change's Fifth Assessment [2]. Recent SLR projections based on semi-empirical [21] or process-based methods [22] attempted to improve the confidence associated with such projections, but the inherent probability models and confidence levels connected with such projections are not easily applied to risk analysis.

Parris et al. [23] highlighted the use of a multiple-scenario approach in evaluating risk established on the basis of tolerance associated with a given risk. A scenario in this context is defined as "a description of future potential conditions in a manner that supports decision-making under conditions of uncertainty" [24]. Accordingly, mean SLR is classified into four scenarios from a "Lowest" of $0.2 \mathrm{~m}$ to the "Highest" level of $2.0 \mathrm{~m}$ with two intermediate scenarios of "Intermediate Low" ( $0.5 \mathrm{~m})$ and "Intermediate High" (1.2 m) (Figure 1). The United States Army Corps of Engineers, similarly, acknowledged that $2.0 \mathrm{~m}$ is a reliable upper bound for future SLR projections. Based on the more recent estimates that incorporate the effects of the ice sheet and glacier melting, Sweet et al. [25] revised the global mean SLR to $2.5 \mathrm{~m}$ by the year 2100 under the "Extreme" scenario. 


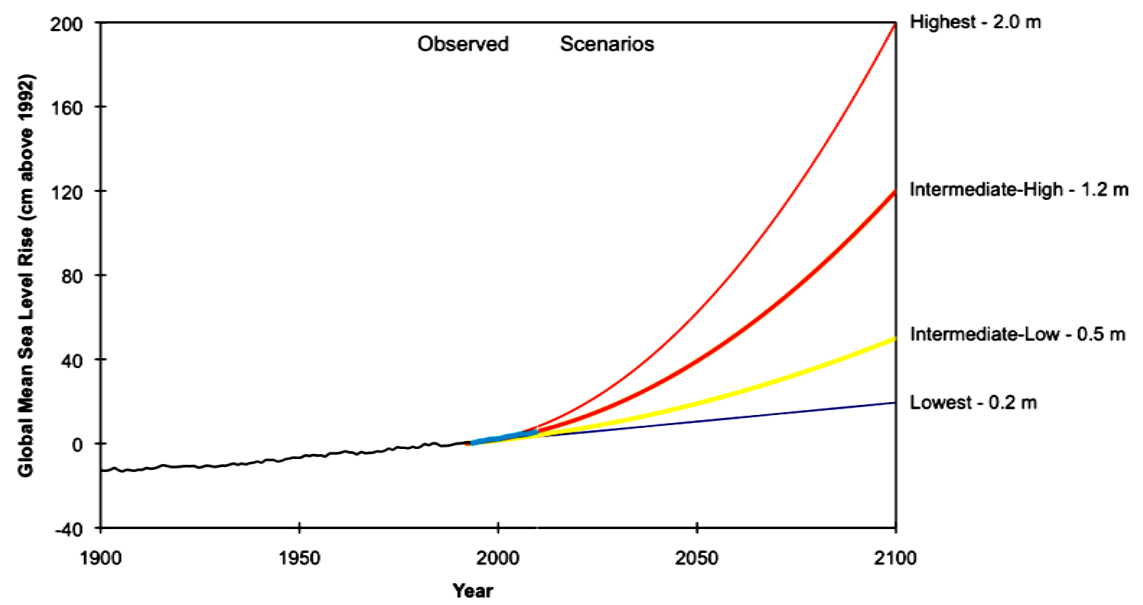

Figure 1. Global mean SLR scenarios [23].

\subsection{Gulf Coast SLR}

The U.S. Gulf Coast is the geographical area in the southern U.S. adjoining the northern portion of the Gulf of Mexico (GoM). The coastal states that have a shoreline on the GoM are Texas, Louisiana, Mississippi, Alabama and Florida. The Gulf Coast is one of the extensively monitored regions for SLR with numerous tide gauges providing decadal-scale sea level data. These long SLR periods are valuable for assessing climate resilience of energy infrastructure investments because many of these facilities are expected to last several decades. The mean sea level trends are assessed for select U.S. stations that span the five Gulf Coast states by using the National Oceanic and Atmospheric Administration's (NOAA) Center for Operational Oceanographic Products and Services historical tide gauge data [26]. Significant variation in SLR is observed among different tide gauge stations along the Gulf Coast (Figure 2).

Coastal Louisiana and some parts of Texas have relatively high SLR compared to other coastal states. The regions of highest SLR are recorded in the Mississippi River Delta plain, where the average rate for the period 1947-2016 is $9.65 \mathrm{~mm} / \mathrm{yr}$ (Eugene Island), closely followed by Grand Isle at $9.09 \mathrm{~mm} / \mathrm{yr}$ [26]. In southwest coastal Louisiana, geologic and physical processes have resulted in high rates of subsidence making the region highly vulnerable compared to their counterparts along the Gulf Coast [27].

In Texas, the rate of SLR ranged from $1.93 \mathrm{~mm} / \mathrm{yr}$ in Port Mansfield to 6.62 $\mathrm{mm} / \mathrm{yr}$ in Galveston. In the eastern Gulf Coast, the lowest rates of SLR were recorded from the tide gauges along Mississippi, Alabama, and Florida coasts.

For Florida, the mean SLR rates averaged around $2.7 \mathrm{~mm} / \mathrm{yr}$ during the measured period. These regional differences in SLR are significant from the standpoint of understanding coastal impacts and risk assessment because of their potentially complex interactions with other mitigating factors including sediment deposition and barrier island buffering [28]. Because of the high tide gauge readings in coastal Louisiana and some parts of Texas, it is fair to assume 


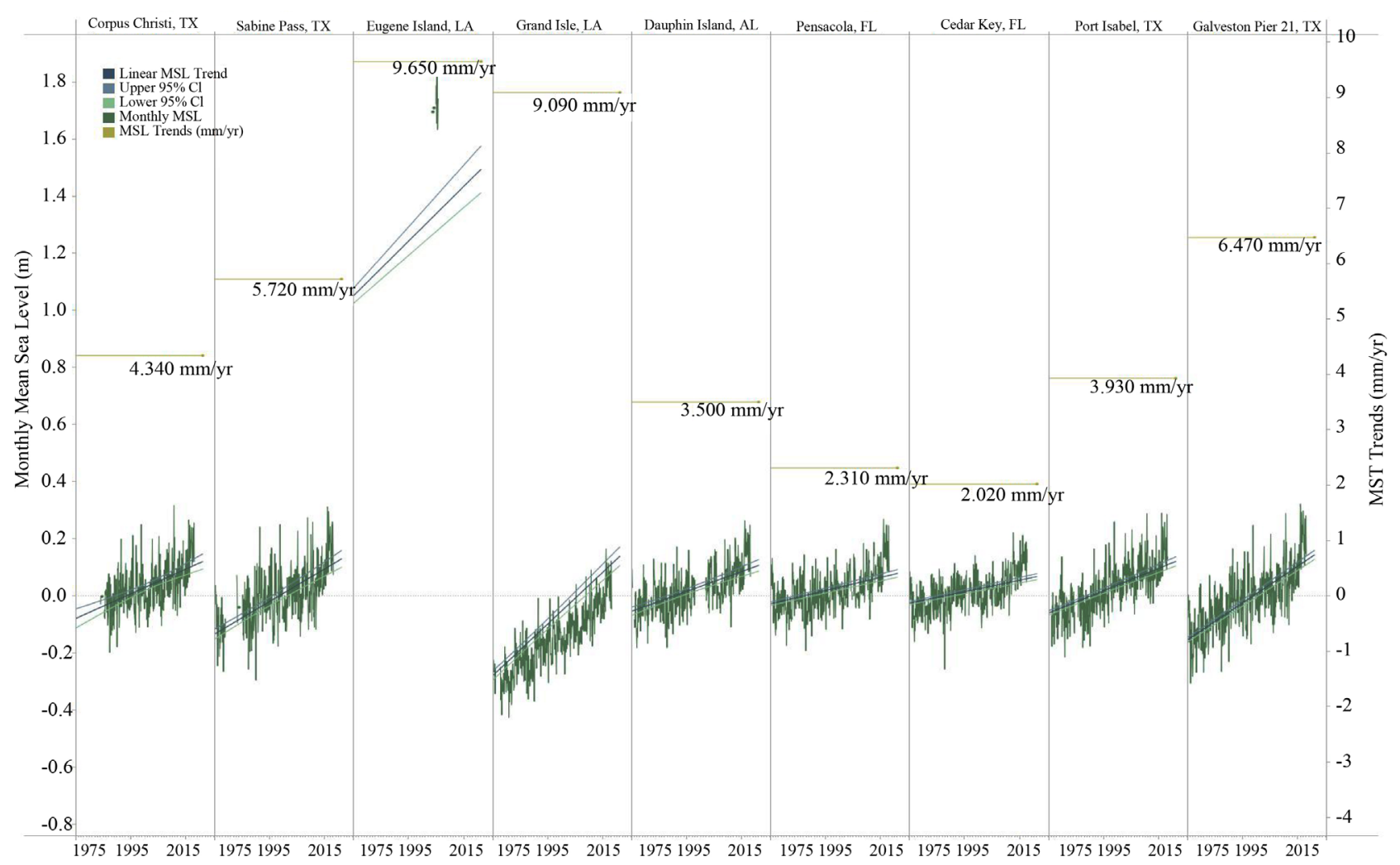

Figure 2. Tide gauge readings from different stations along the Gulf Coast.

that these areas will see SLR in the upper bounds of future scenarios.

\subsection{Flood Frequency and Duration}

One of the ancillary effects of SLR that has been well established in past research is tidal flooding [29]. Many coastal communities have to deal with more frequent and extended flooding in the next few decades even before the rising sea levels lead to greater inundation extent [29]. Since the 1960s, annual occurrences of tidal flooding above local thresholds have seen a 5-to-10-fold increase. As relative sea level increases, high tides may cause flooding even in the absence of hurricanes and storm surges. Figure 3 shows the surge in the number of flood events and flood duration as sea level rises to hypothetical scenarios of $0.5 \mathrm{~m}$ and 1.0 from current mean sea levels at different tide gauge stations along the Gulf Coast. At most locations examined across the Gulf Coast, a $0.5-\mathrm{m}$ increase in the mean sea level leads to flood frequency that is 50 times greater than the current levels while also showing a significant increase in flood duration because flood level thresholds are reached more often. For most areas, a $0.5-\mathrm{m}$ increase in sea level results in frequent flooding events with shorter tidal cycle durations. In some cases, as sea level rises to $1.0 \mathrm{~m}$, the number of flooding events decreases while the durations increase substantially. Justifiably, flood frequency is expected to be greatest in low-lying areas that are supplemented by high SLR levels. Any further acceleration in SLR that is predicted to occur this century is expected to 


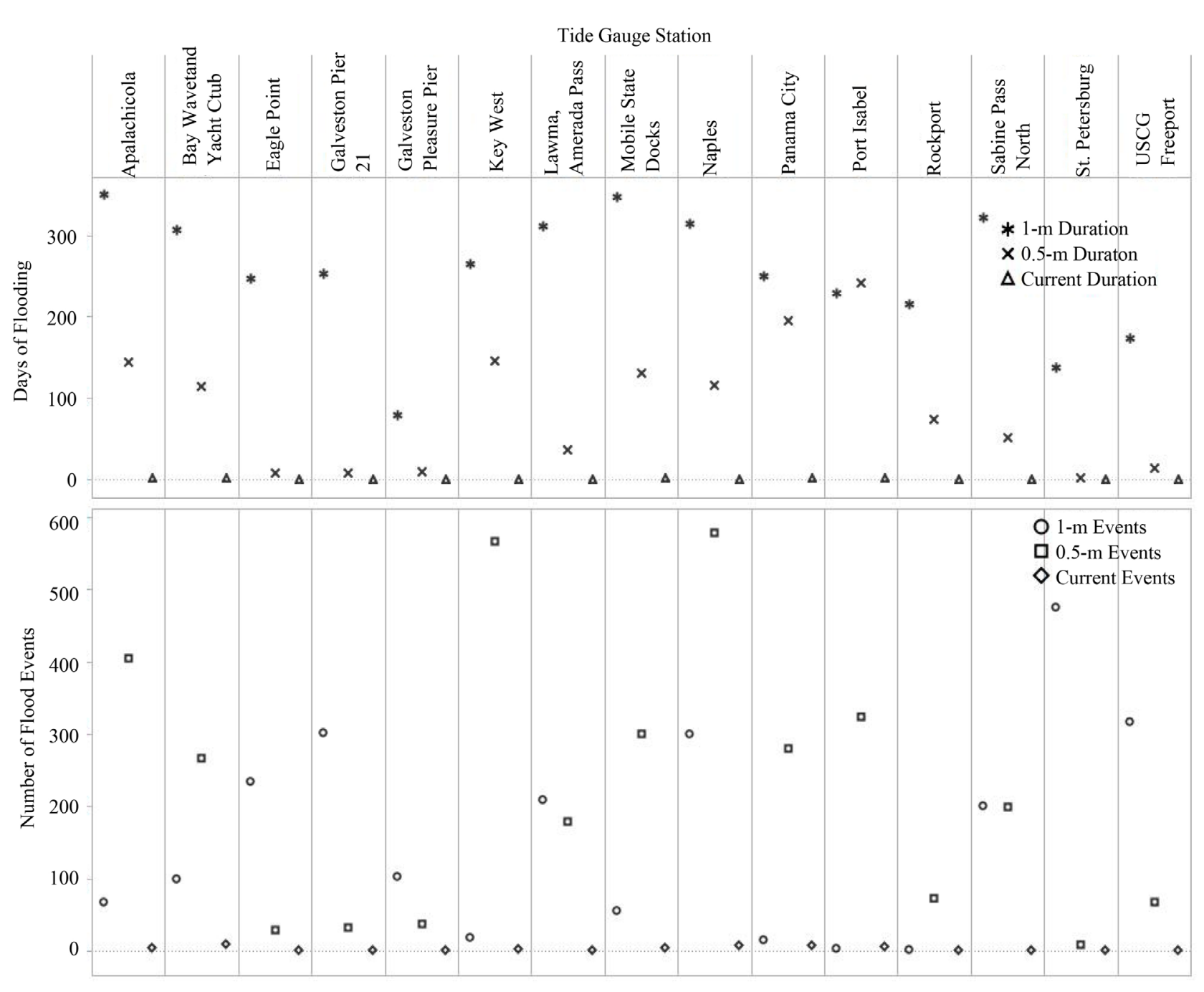

Figure 3. Flood duration and frequency at tide gauge stations.

strengthen high tide flooding impacts with increasing frequency.

\subsection{Overview of Gulf Coast Energy Industry}

The Gulf Coast is the most prominent energy producing and processing regions in the U.S., accounting for $45 \%$ of the nation's refining capacity and $51 \%$ of its natural gas processing capacity (U.S. Energy Information Administration (EIA)). The Gulf Coast is also the largest domestic supplier of transportation fuels. Over the last six decades, this region has seen tremendous growth in physical infrastructure development to support various onshore and offshore oil and gas exploration and production (E\&P) activities and is a critical component of the interconnected North American energy network.

Most of these infrastructure facilities are located near coastal areas in order to facilitate additional transportation access particularly for international commodity and product flows (Figure 4). The Gulf Coast encompasses two of largest energy-producing states in the U.S.: Texas and Louisiana. In 2016, Texas 


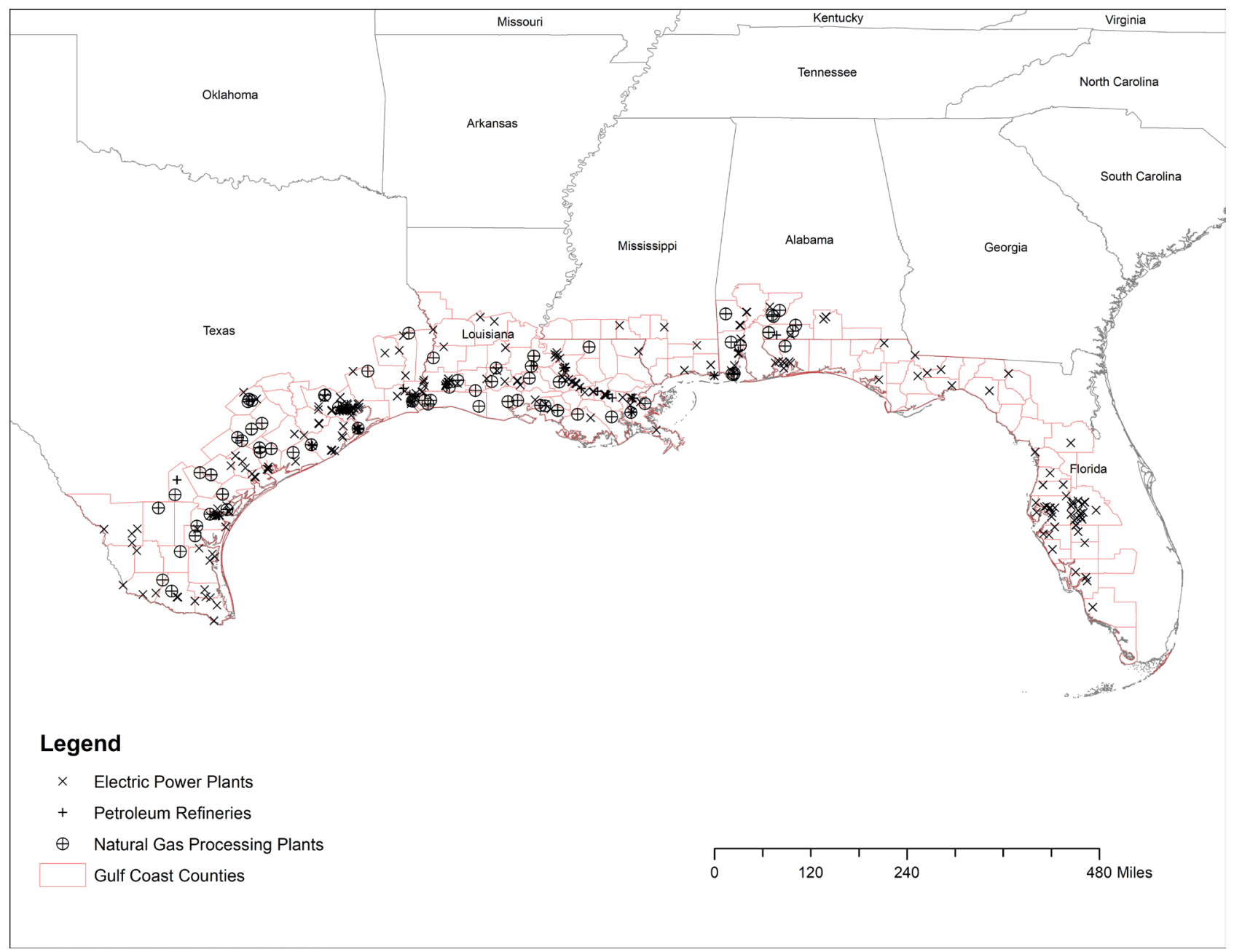

Figure 4. Energy infrastructure types assessed in this study include refineries, gas processing plants and power generators.

produced more than a third of the nation's crude oil and accounted for $30 \%$ of total U.S. refining capacity.

\subsubsection{Refineries}

Petroleum refineries process crude oil through a series of distillation facilities separating crude oil into its component parts to generate refined products such as gasoline, diesel, jet fuel, and heating oil, to name a few. These facilities were originally developed at the turn of the twentieth century and continue to operate, by expanding their effective capacities through a series of expansions, upgrades, and efficiency improvements often referred to as "capacity creep." The region's refineries were first developed to process crude oil produced within the region and, starting in the 1970s, to increasingly process crude oils from foreign sources such as Saudi Arabia, Canada, Mexico, and Venezuela. Most of the largest refineries are located along the Texas and Louisiana coasts with a number of smaller facilities located in Mississippi and Alabama.

The U.S. EIA reports that 2017 total crude distillation capacity of all refineries in the U.S. is 19 million barrels per day (MMbpd) [30]. However, the individual 
capacity of each facility in the region can vary from less than $100 \mathrm{Mbpd}$ to over $500 \mathrm{Mbpd}$. Texas is the leading petroleum refining state, processing more than 5.6 MMbpd crude oil from its 29 operable refineries. Louisiana has the second largest refining capacity contributing to $17 \%$ of nation's capacity.

The successful operation of a refinery depends on the timely supply of feedstock, electricity, and workforce availability. Any disruption in this chain greatly affects the operational dynamics of refineries. The 2004 and 2005, and later 2017 tropical seasons had considerable impacts on most Gulf Coast refineries either through facility-specific damage or through feedstock interruptions, power outages, and/or refined product transportation interruptions.

\subsubsection{Natural Gas Processing Plants}

Natural gas processing plants are midstream facilities that serve as an important link between the wellhead and the burner tip. These facilities "clean" natural gas to remove moisture and impurities as well as, most importantly, the heavier hydrocarbons that are in the production gas stream. These heavier hydrocarbons include ethane, propane, butane and other commodities often referred to collectively as natural gas liquids (NGLs). These NGLs have high commercial value as energy and chemical-industry feedstock.

Most of the original facilities in the region were developed to process conventional natural gas produced along the onshore areas of the region or, increasingly from the offshore and deepwater regions of the Gulf of Mexico. While GOM natural gas production is down relative to its historical trends, these facilities are still important components of the overall natural gas value chain. The EIA reports that in 2014 there were 554 active natural gas processing plants in the U.S. with a total daily processing capacity of more than 76 billion cubic feet (Bcf) [30]. Texas leads the nation in natural gas processing capacity with about 24 Bcfd of capacity as of 2014. With dry natural gas production forecasted to increase to more than $93.5 \mathrm{Bcfd}$ by 2030 , there has been a substantial increase in natural gas processing infrastructure over the past decade with investments ranging in billions for new construction or expansions. Power generation is another important factor that will contribute to the projected increase in natural gas demand by 2030. According to the EIA, this demand is projected to increase from 22.2 Bcfd in 2013 to more than 31.0 Bcfd by 2030.

\subsubsection{Electric Power Generation}

An electric power system is a unified, physically-connected and operated group of facilities that are involved in the generation, transmission, and distribution of power. Apart from its use for residential and commercial purposes, electricity is an essential input for the industrial operations along the Gulf Coast. Electric power generators are typically categorized by the fuel source they use and subcategorized by their specific operating technology or "prime mover". Although power generation along the Gulf Coast includes different sources, including fossil fuels, nuclear and renewables, natural gas is the primary fuel source. 
There are 3645 electric utilities with 7494 plants in the United States with 456 utilities and 731 operable plants located in the study region of Texas, Louisiana, Mississippi, Alabama and Florida [30]. Each plant may have several generating units using different sources of fuel. The total generating capacity in the U.S. is 1167 gigawatts (GW).

Extreme weather in the past has caused substantial electricity outages, as power plants and transmission infrastructure were affected by high winds and significant flooding. At its peak, Hurricane Harvey (2017) affected more than 10,000 megawatts (MW) of electricity generating capacity in Texas. Similarly, 17 power generating facilities in Louisiana with a combined capacity of $5000 \mathrm{MW}$ were shut down because of physical damage or flooding from Hurricane Katrina.

\section{Methods and Data}

\subsection{Study Area}

The study area consists of 139 coastal counties along the GoM as defined by the NOAA Strategic Environmental Assessments Division (Figure 5). According to NOAA, "These are counties that meet one of the following criteria: 1) at least $15 \%$ of a county's total land area is located within the Nation's coastal watershed; or 2) a portion of or an entire county accounts for at least $15 \%$ of a coastal cataloging unit." In the study area, Texas and Florida account for 41 and 40 coastal counties respectively, while Louisiana has 38 parishes considered as coastal. There are also 8 counties from Alabama and 12 from Mississippi that meet one or both of the above criteria. These five states also account for a total shoreline

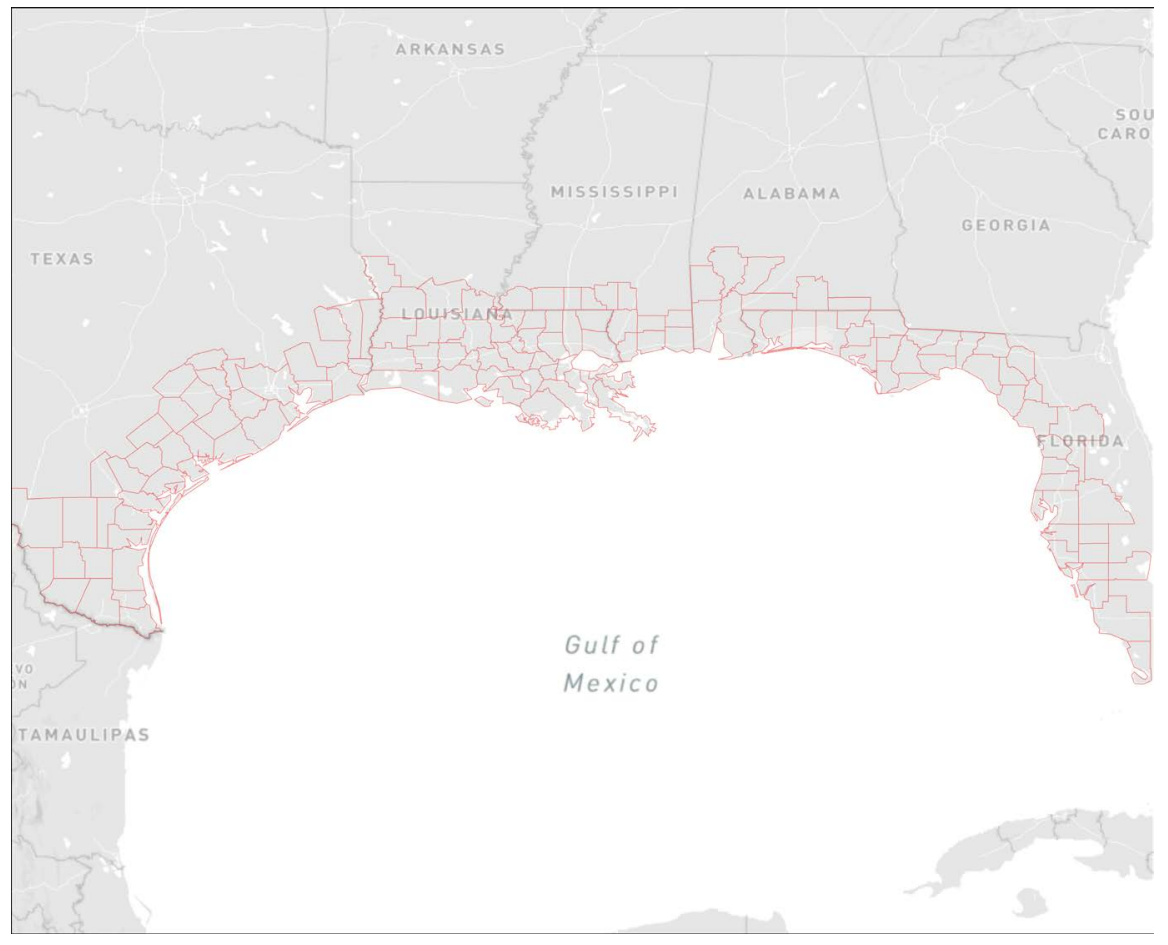

Figure 5. Study area includes 139 counties along the Gulf Coast. 
of $17,141 \mathrm{mi}$, with Louisiana contributing 7721 of these miles from its barrier islands, extensive wetlands, and the Mississippi River Delta.

\subsection{Inundation Model}

The model used for estimating future SLR inundation depth and at-risk energy infrastructure facilities is adapted from the one developed by the NOAA Office for Coastal Management (Figure 6). The model input consists of Digital Elevation Model (DEM) raster data, tidal surface values for the region and point locations of energy facilities for the Gulf Coast region [31]. To assess potential effects of projected SLR, present inventory of critical energy infrastructure is mapped along the Gulf Coast using a Geographical Information System (ArcGIS 10.5) based on three different plausible SLR scenarios $(0.61 \mathrm{~m} \mathrm{(2ft}), 1.22 \mathrm{~m}(4 \mathrm{ft})$ and $1.83 \mathrm{~m}(6 \mathrm{ft}))$ to determine the potential impacts on coastal energy infrastructure.

\subsection{Geospatial Data}

The SLR inundation extent data for the different SLR scenarios is obtained from the Office for Coastal Management Digital Coast website [31] for the five Gulf Coast states. These data are available in ESRI geodatabase as both vector shapefiles and raster datasets with a resolution varying from $3 \mathrm{~m}$ to $10 \mathrm{~m}$. These data illustrate future SLR inundation footprint and relative depth along with potential flooding from current mean higher high water datum to a six-foot SLR. Figure 7 shows a representative extent of inundation under three different SLR scenarios for the Central Gulf Coast.

The estimation of future inundation based on predicted SLR and elevation involves many unknowns, including wetland restoration, barrier island dynamics, local elevation changes and subsidence, which make the inundation areas depicted in the SLR shapefiles and raster datasets not very precise. Hence, it is vital to focus on both the extent of inundation and the confidence levels associated with these inundation layers at different SLR scenarios. Hence, confidence level maps of these inundation layers are also downloaded from [31]. These confidence estimates represent the elevation and tidal correction errors. While determining the infrastructure facilities that are potentially at risk of inundation, areas with high degree of confidence are distinguished from areas with high degree of uncertainty.

\subsection{Energy Infrastructure Assessment}

The critical energy sub-sectors selected are petroleum refineries, natural gas processing plants, and power generation plants as overviewed earlier. These infrastructure types are selected because of the high concentration and reliance on those energy types, and their role in the energy supply chain. Historically, these were most affected facilities in the region during and in the aftermath of severe weather and hurricanes. 


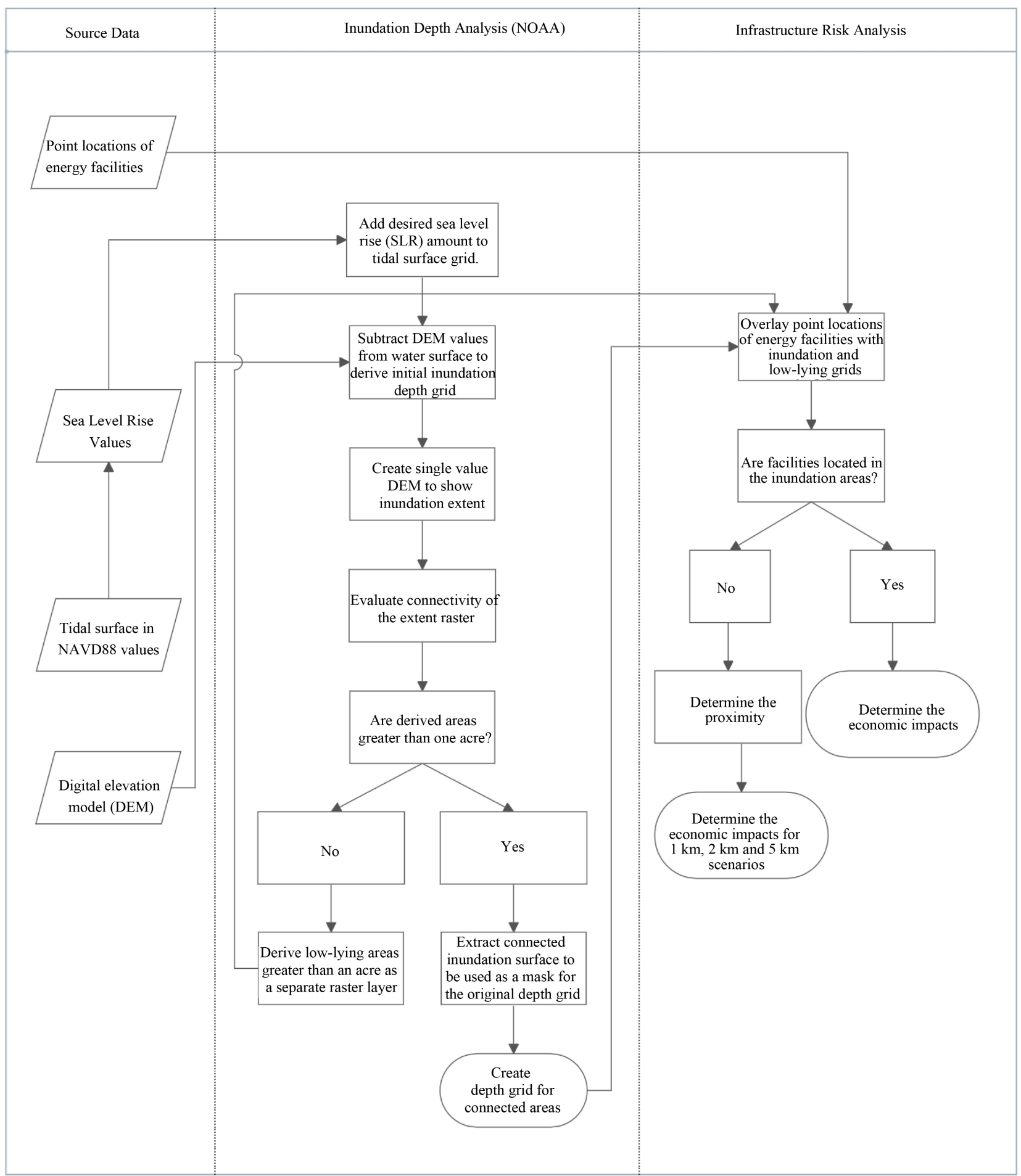

Figure 6. Model framework used to determine inundation extent for different SLR scenarios. The SLR depth grids for different scenarios are obtained from NOAA [31].

The possibility of structural risk to these facilities was examined because of inundation with a particular emphasis on the refining, processing and power generation capacity that may be impacted because of potential perturbations to the energy systems. Geospatial data with detailed facility-level data for each 


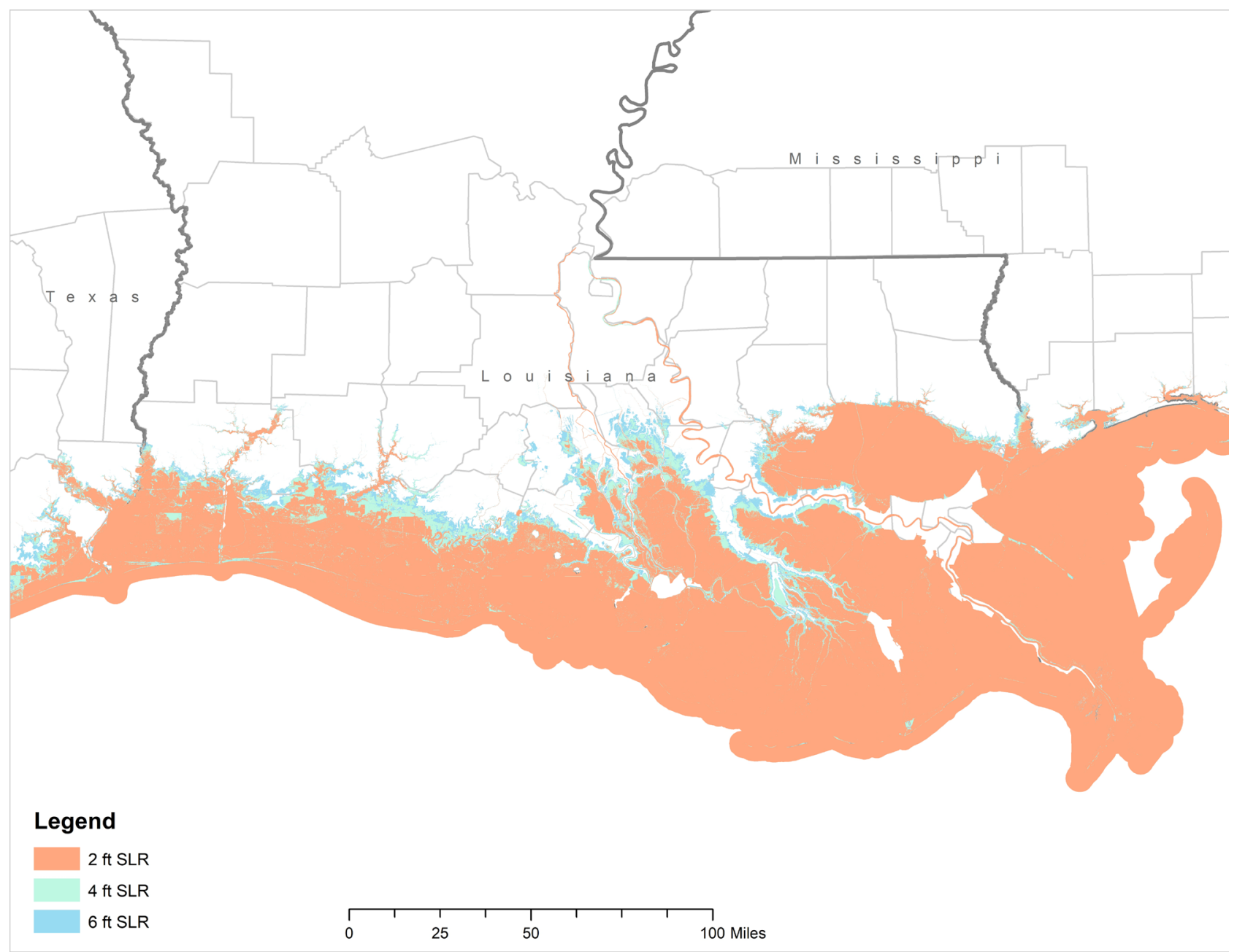

Figure 7. Three different SLR scenarios used in inundation analysis.

infrastructure type are obtained from the EIA [30].

The 2017 EIA-820 refinery capacity report provided detailed facility-level data. Similarly, for natural gas processing plants, EIA-757 data based on a triennial survey is used for assessing the effect of extreme weather on natural gas processing infrastructure. The last updated data from this survey is for the year 2014. Power plant data is obtained from the EIA-860 Annual Electric Generator report for the year 2015. Each infrastructure type is intersected with inundation extents for future SLR scenarios of $0.61 \mathrm{~m}(2 \mathrm{ft}), 1.22 \mathrm{~m}(4 \mathrm{ft})$ and $1.83 \mathrm{~m}(6 \mathrm{ft})$, and the locations of existing refinery, natural gas processing and electric generator facilities that are in the inundation zones are identified.

For facilities that are not directly in the inundation zone, a proximity analysis is carried out to determine the likelihood of a facility being impacted by SLR and resulting flooding and storm surges from receding shorelines. In essence, structure proximity to the future shoreline is used as a proxy for storm surge and flood impacts. Based on the proximity of these facilities, ones that are within 1 $\mathrm{km}, 2 \mathrm{~km}$ and $5 \mathrm{~km}$ from the inundation zones are identified. National Oceanic 
and Atmospheric Administration identifies that some Gulf Coast areas are extremely vulnerable to storm surges because of a flat continental shelf and low-lying areas extending well inland. Because of the complex interaction between storm surges, flooding and local geophysical characteristics, there no single set of variables that can be applied to all instances for these proximal facilities [32].

\section{Results}

\subsection{Inundation Extent vs. SLR Scenarios}

The inundation analysis shows that an additional $19,496 \mathrm{~km}^{2}$ of coastal Gulf is at

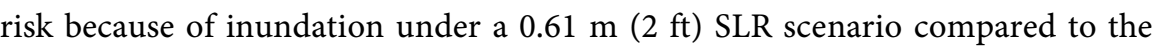
base scenario where there is no risk from SLR. This corresponds to a $29 \%$ increase of land area that will be under the coastal inundation zone compared to a no SLR scenario. This inundation area grows by a further $6568 \mathrm{~km}^{2}$ at $1.22 \mathrm{~m} \mathrm{(4}$

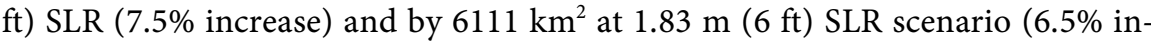
crease).

An illustrative example of the inundation extent in the Mississippi River Delta plain for different SLR scenarios against the location of energy facilities is shown in Figure 8. Areas with a high degree of probability of inundation are distinguished from the ones with the low certainty of inundation while identifying the facilities at risk.

\subsection{Potential Effects on Petroleum Refining}

The Chevron Refinery located in Pascagoula (Mississippi), with a capacity of 370,000 barrels per day (bpd), is the only facility that is directly located in the

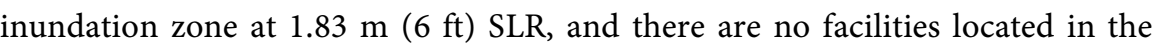

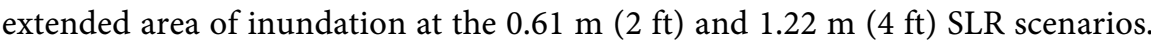
However, the potential risk of inundation and flooding because of the proximity of these facilities at increased inundation level at $2 \mathrm{ft}, 1.22 \mathrm{~m}(4 \mathrm{ft})$ and $1.83 \mathrm{~m}(6$ ft) SLR scenarios shows a much higher impact to the refineries (Figure 9). Potentially, there are 37 refineries at risk because of their proximate nature to the receding shoreline. With increased inundation inland at $1.83 \mathrm{~m}(6 \mathrm{ft}) \mathrm{SLR}$, there are more facilities located within the $1 \mathrm{~km}$ and $2 \mathrm{~km}$ buffer regions compared to lower SLR scenarios. The estimate is a potential for about 8.9 MMbpd refining capacity that is affected because of these future SLR levels based on current operable distillation capacity numbers. This amounts to $96 \%$ of the GoM capacity and about a little less than a half of the country's capacity.

\subsection{Potential Effects on Natural Gas Processing}

There are a total of 15 facilities located in the inundation extents from future SLR scenarios (Table 1, Figure 10) with a combined capacity of $6.0 \mathrm{Bcfd}$. This is about a one-third of the total processing capacity in the study region and $8 \%$ of the nation's capacity. Nine of these facilities are located in inundation zones 

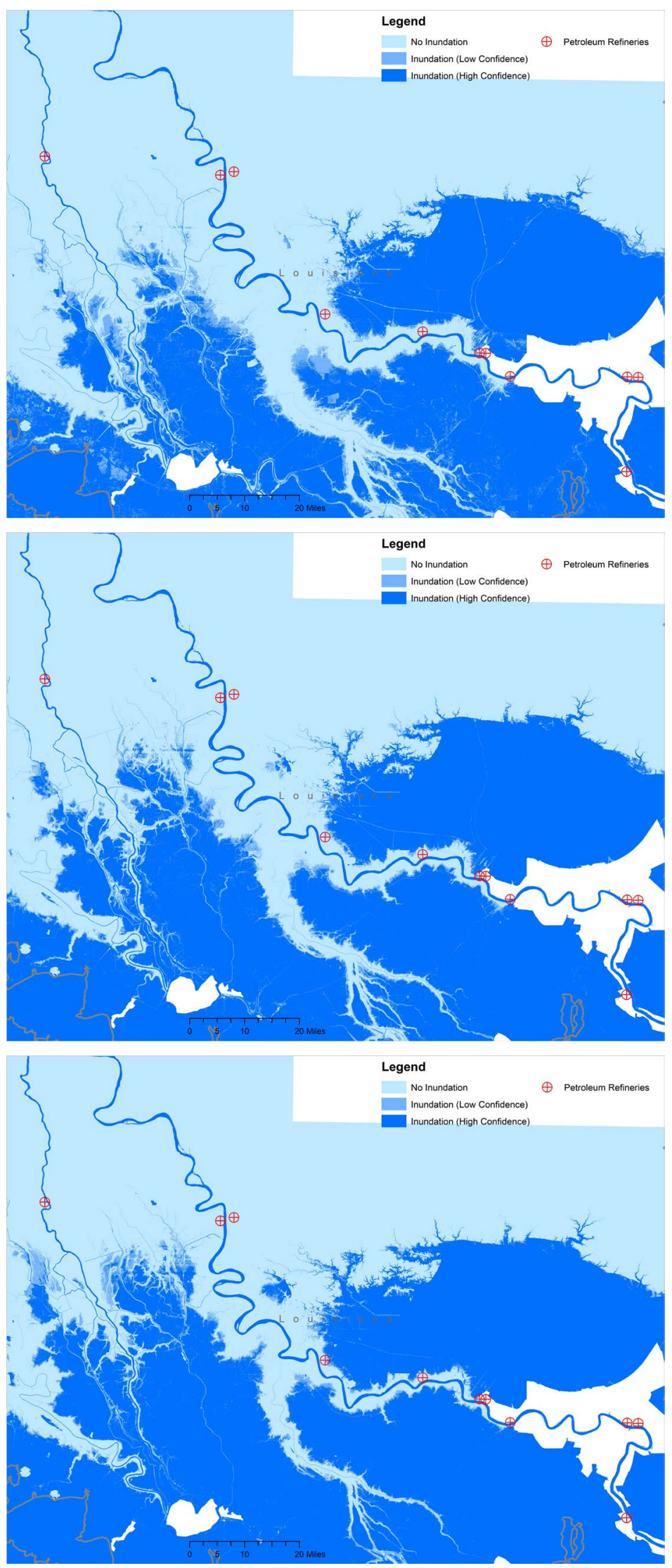

(a) 


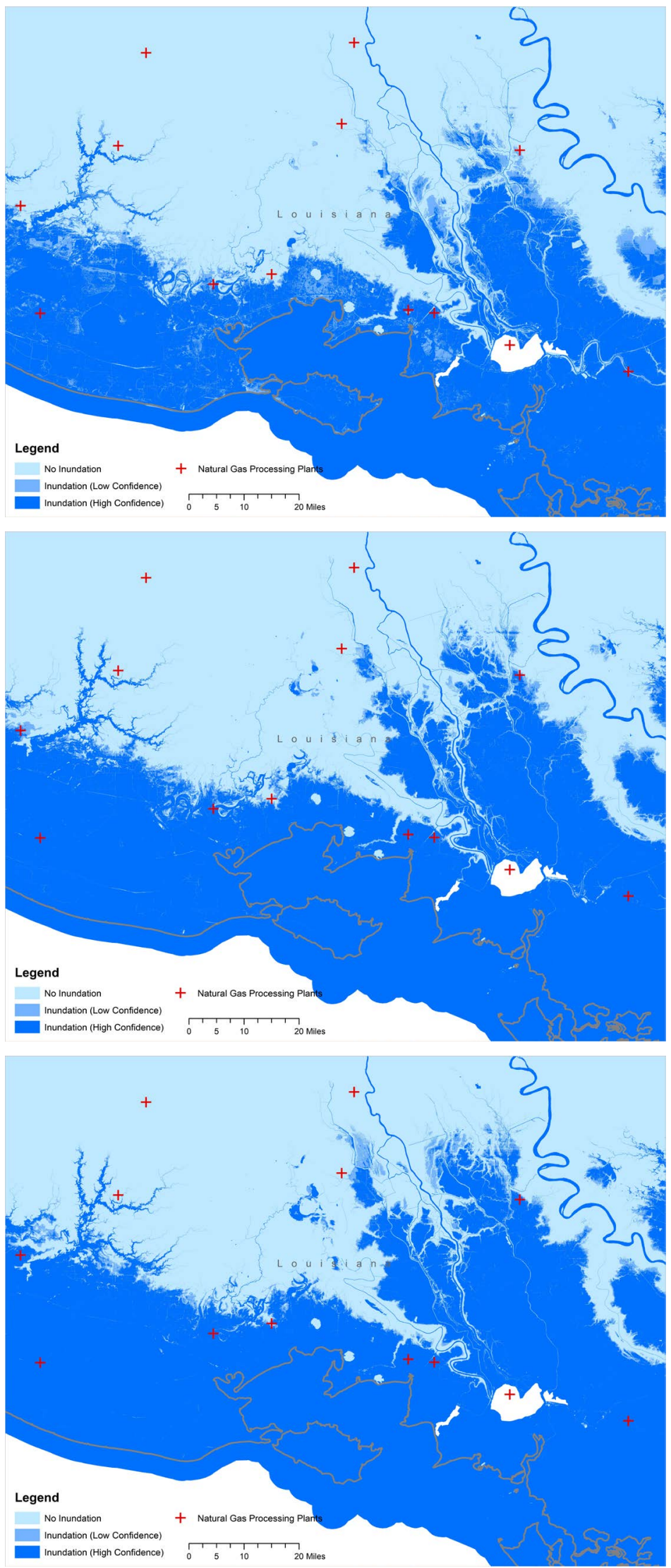

(b) 

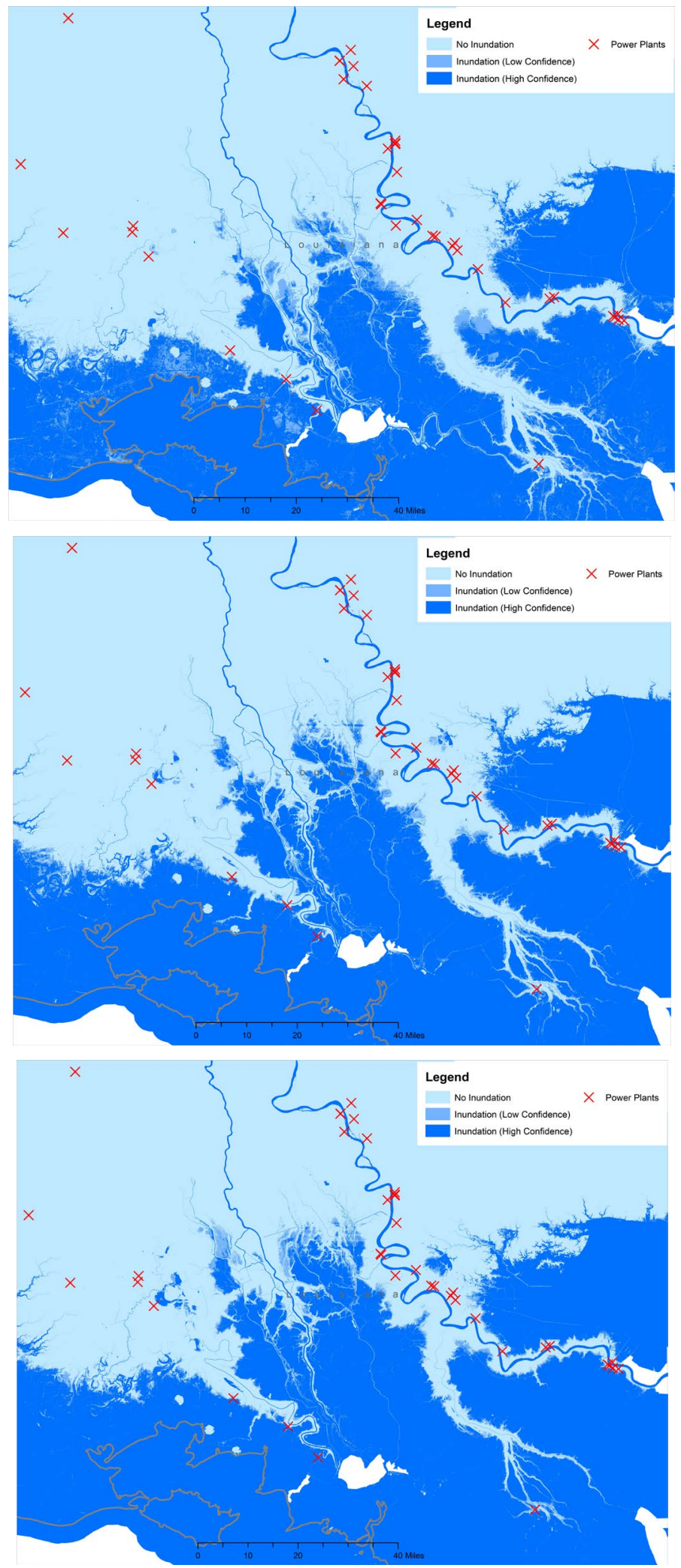

(c)

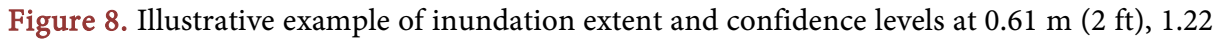
$\mathrm{m}(4 \mathrm{ft})$ and $1.83 \mathrm{~m}(6 \mathrm{ft})$ SLR scenarios (left to right) with infrastructure facilities overlaid: (a) Petroleum refineries; (b) Natural gas processing plants; and (c) Power plants. 


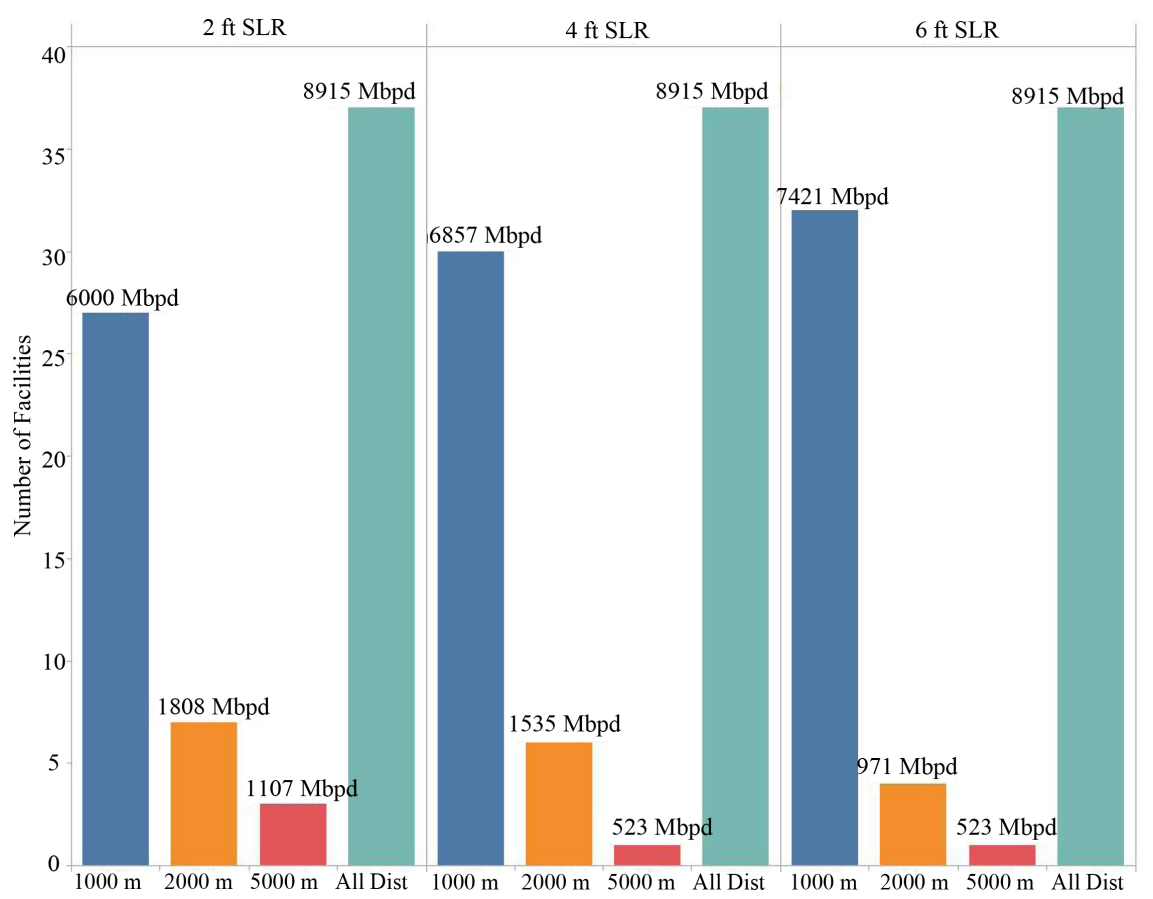

Figure 9. Proximity analysis of refineries along the Gulf Coast at $0.61 \mathrm{~m}(2 \mathrm{ft}), 1.22 \mathrm{~m} \mathrm{(4}$ $\mathrm{ft})$ and $1.83 \mathrm{~m}(6 \mathrm{ft})$ SLR scenarios. Bars show the number of refineries and the numbers above show the estimated distillation capacity (in thousand barrels per day (Mbpd)) that is potentially impacted.

Table 1. At-risk natural gas processing plants at different SLR scenarios.

\begin{tabular}{|c|c|c|c|c|c|c|}
\hline & $\mathrm{SLR}^{\mathrm{a}}$ & & Facility & Operator & $\begin{array}{l}\text { Capacity } \\
\text { (MMcfd) }\end{array}$ & Confidencel $^{\mathrm{b}}$ \\
\hline $\begin{array}{c}1.83 \mathrm{~m} \\
(6 \mathrm{ft})\end{array}$ & $\begin{array}{c}1.22 \mathrm{~m} \\
(4 \mathrm{ft})\end{array}$ & $\begin{array}{c}0.61 \mathrm{~m} \\
(2 \mathrm{ft})\end{array}$ & & & & \\
\hline \multirow{16}{*}{1} & 0 & 0 & Plaquemine Plant & EnLink LIG Liquids, LLC & 225 & High \\
\hline & \multirow{15}{*}{1} & \multirow{5}{*}{0} & Gibson Plant & EnLink LIG Liquids, LLC & 110 & High, High \\
\hline & & & Lowry Gas Plant & Targa Resources & 220 & High, High \\
\hline & & & North Terrebonne Plant & Enterprise Gas Processing LLC & 1100 & High, High \\
\hline & & & PSI Kaplan Plant & PSI Midstream Partners, LP & 300 & High, High \\
\hline & & & Williams Mobile Bay Processing Plant & Williams Mobile Bay Producer Services, LLC & 700 & High, Low \\
\hline & & \multirow{10}{*}{1} & Barracuda Gas Plant & Targa Resources & 200 & High, High, High \\
\hline & & & Burns Point Plant & Enterprise Gas Processing, LLC & 160 & High, High, High \\
\hline & & & Cameron Meadows Gas Plant & PSI Midstream Partners, LP & 125 & High, High, Low \\
\hline & & & Gillis Gas Plant & Targa Field Services LLC & 180 & High, High, High \\
\hline & & & Grand Cheniere Plant & Plains Gas Solutions & 120 & High, High, High \\
\hline & & & Larose Processing Plant & Williams Field Services Group LLC & 600 & High, High, High \\
\hline & & & Neptune Gas Plant & Enterprise Gas Processing LLC & 650 & High, High, High \\
\hline & & & Stingray Gas Plant & Targa Resources & 300 & High, High, Low \\
\hline & & & Toca Gas Plant & Enterprise Gas Processing, LLC & 1100 & High, High, High \\
\hline & & & Total & & 6090 & \\
\hline
\end{tabular}

a. A " 1 " under an SLR scenario indicates that the facility is affected at that level; " 0 " indicates that the facility is located outside the inundation zone for that scenario. b. Inundation confidence level for the SLR scenario(s) with value " 1 " from left to right. 


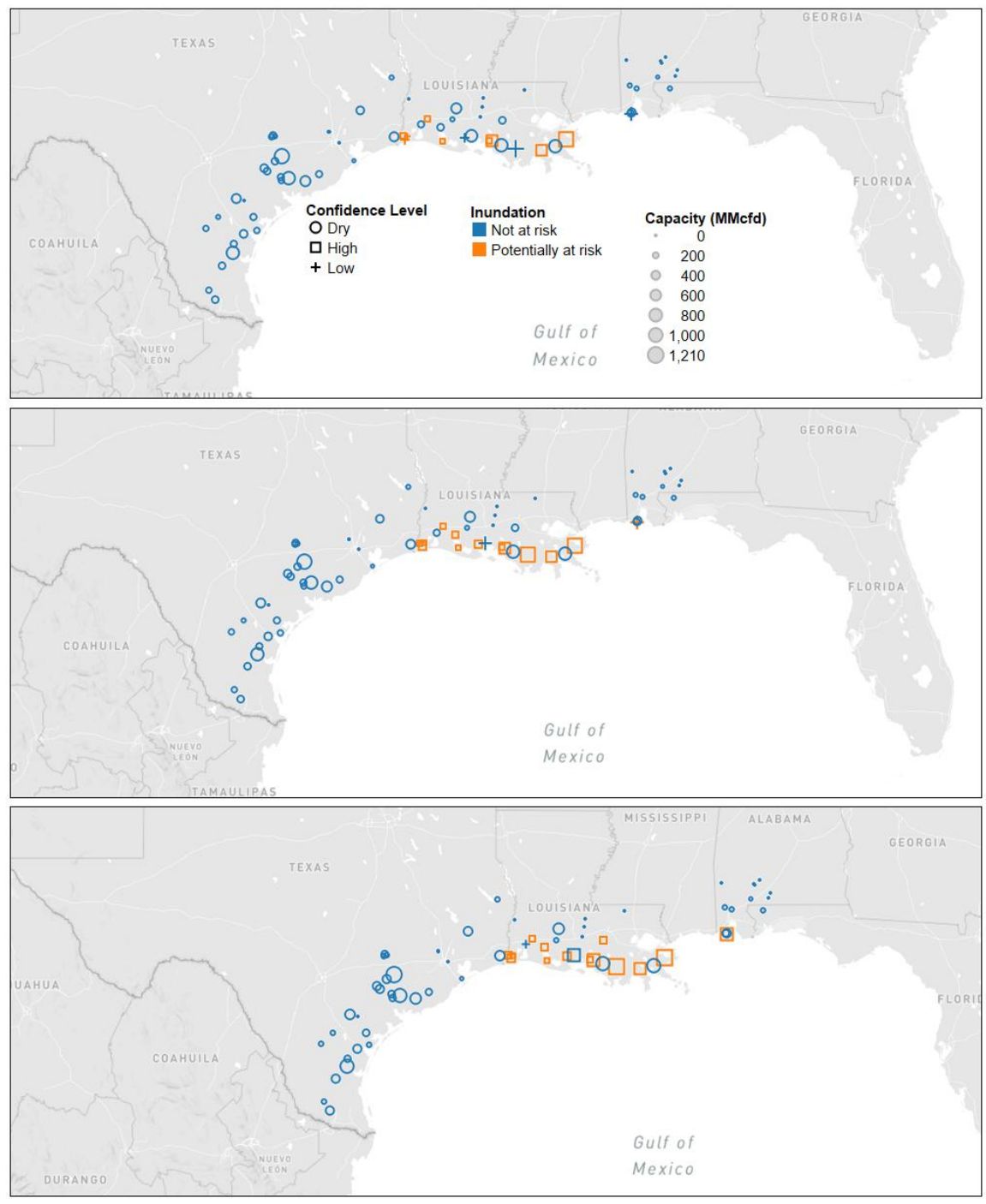

Figure 10. Natural gas processing plants that are potentially at risk because of increased inundation from $0.61 \mathrm{~m}(2 \mathrm{ft}), 1.22 \mathrm{~m} \mathrm{(4ft)}$ and $1.83 \mathrm{~m}(6 \mathrm{ft})$ SLR scenarios (top to bottom).

from all three scenarios, while five facilities are located in $1.83 \mathrm{~m}(6 \mathrm{ft})$ and 1.22

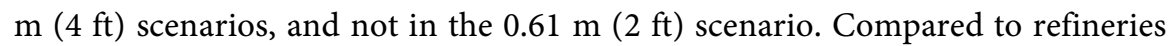
and power generating plants, more NGP facilities are located in the direct zone of inundation even at lower SLR scenarios.

Figure 11 shows the number of affected facilities at different SLR and distance thresholds. In total, there are 33 facilities that are in close proximity to the in-

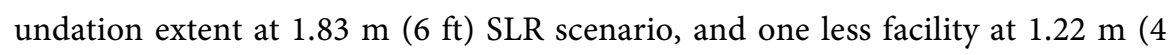
$\mathrm{ft})$ and $0.61 \mathrm{~m}(2 \mathrm{ft})$ scenarios. The combined processing capacity of these facilities that is affected is about $10 \mathrm{Bcfd}$ at both $0.61 \mathrm{~m}(2 \mathrm{ft})$ and $1.22 \mathrm{~m} \mathrm{(4ft)} \mathrm{SLR}$ scenarios, which equates to $13 \%$ of the total U.S. processing capacity. The facilities at lower distance thresholds comprise a majority of these at-risk facilities, accounting for more than three-fourths of the affected processing capacity in different SLR scenarios. 


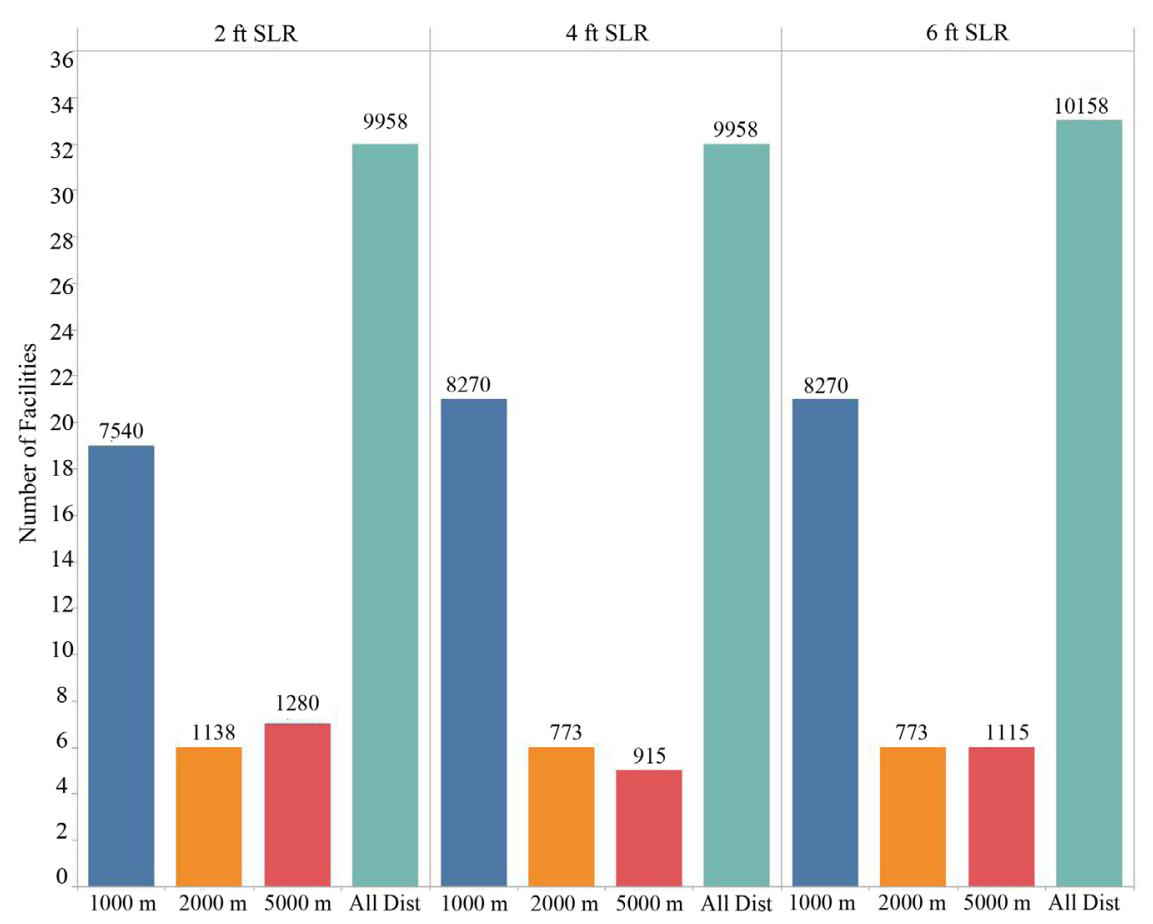

Figure 11. Proximity analysis of natural gas processing facilities along the Gulf Coast at $0.61 \mathrm{~m}(2 \mathrm{ft}), 1.22 \mathrm{~m}(4 \mathrm{ft})$ and $1.83 \mathrm{~m}(6 \mathrm{ft})$ SLR scenarios.

\subsection{Potential Effects on Power Generation}

In total, there are 16 power generators that are located in the inundation extents from future SLR scenarios (Table 2, Figure 12) with a combined capacity of 608 MW. This is only a small fraction of the total combined capacity in the region. However, proximity analysis of these facilities shows that 355 generators are located within $1 \mathrm{~km}$ of the inundation zone in the highest SLR scenario of $1.83 \mathrm{~m}$ (6 ft) (Figure 13) with about a half of the total capacity in the study area at risk. If the distance threshold is increased to $2 \mathrm{~km}$, an additional 104 generators totaling $9 \mathrm{GW}$ will be potentially at risk. Under $0.61 \mathrm{~m}(2 \mathrm{ft})$ and $1.22 \mathrm{~m}(4 \mathrm{ft})$ SLR scenarios, 311 and 341 generators are within $1 \mathrm{~km}$ of the inundation zone.

\section{Discussion}

\subsection{Future Adaptation and Resilience}

Because of the economic dependence of coastal communities on the energy industry in the region, Gulf Coast will benefit from adaptive practices to improve resilience to natural hazards associated with SLR. Hurricane storm surges and coastal flooding will continue to pose growing problems to critical infrastructure more than ever before. As part of these adaptive measures, some local and regional governments are already becoming more coordinated in planning and upgrading at-risk infrastructure as a means to combat SLR.

As energy infrastructure typically has long operating lifetimes, risk prevention, adaptation strategies, and protective measures are required to reduce potential adverse effects [33]. Understanding infrastructure characteristics that make 


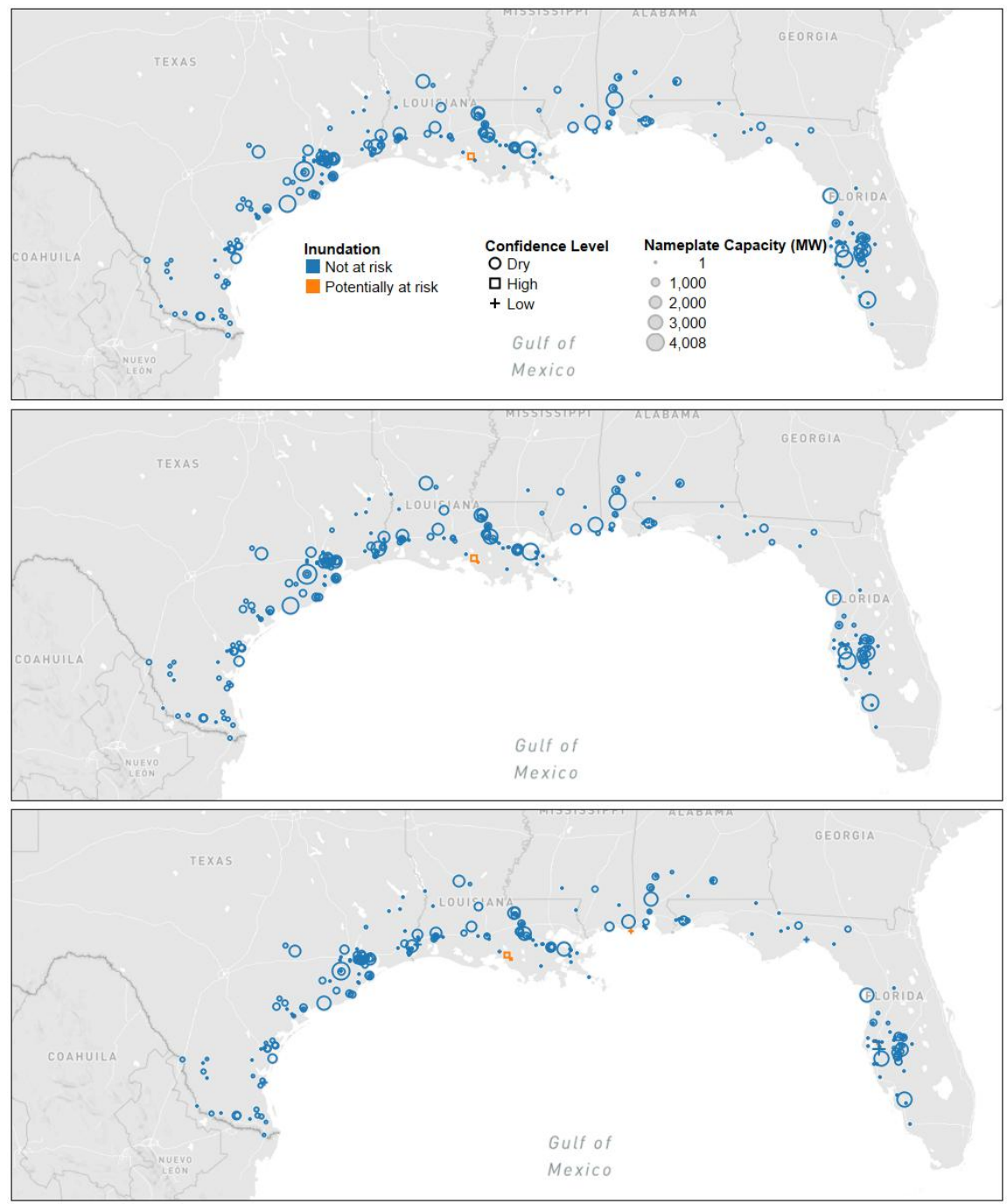

Figure 12. Power generation plants that are potentially at risk because of increased inundation from $0.61 \mathrm{~m}(2 \mathrm{ft}), 1.22 \mathrm{~m}(4 \mathrm{ft})$ and $1.83 \mathrm{~m}(6 \mathrm{ft})$ SLR scenarios (top to bottom).

them vulnerable to impacts of SLR and a study of historical events that have compromised this infrastructure are important for understanding the means for adaptation [34]. Keeping in mind the future changes that will help them overcome or withstand future conditions, it is imperative that these future changes to the environment and coastal ecosystem are considered in new facility construction as reactive measures can be costly.

Further analysis and additional information are needed to determine the extent to which exposed facilities would be damaged or debilitated and to project changes in energy infrastructure that could occur in the coming decades, including possible investments in infrastructure hardening and other resilience measures. Furthermore, energy system modeling is needed to understand the extent to which damaged facilities could disrupt energy services and for how long. Future research may also focus on understanding the implications of these findings for energy system reliability and resilience. 
Table 2. At-risk power generation plants at different SLR scenarios.

\begin{tabular}{|c|c|c|c|c|c|c|c|}
\hline & $\mathrm{SLR}^{\mathrm{a}}$ & & Generator ID & Utility ID & Plant Name & $\begin{array}{c}\text { Capacity } \\
\text { (MW) }\end{array}$ & Confidence $^{\mathrm{b}}$ \\
\hline $1.83 \mathrm{~m}(6 \mathrm{ft})$ & $1.22 \mathrm{~m}(4 \mathrm{ft})$ & $0.61 \mathrm{~m}(2 \mathrm{ft})$ & & & & & \\
\hline \multirow[t]{16}{*}{1} & & & 148 & 12686 & Chevron Oil & 16.6 & Low \\
\hline & & & 149 & 12686 & Chevron Oil & 16.6 & Low \\
\hline & & & 150 & 12686 & Chevron Oil & 18.0 & Low \\
\hline & 0 & 0 & 151 & 12686 & Chevron Oil & 18.0 & Low \\
\hline & & & 152 & 12686 & Chevron Oil & 101.3 & Low \\
\hline & & & 835 & 57389 & IKEA Tampa 042 & 1.0 & High \\
\hline & & & 845 & 58749 & Rentech Nitrogen Pasadena Cogeneration & 15.4 & High \\
\hline & & & 590 & 18483 & Howard F Curren Advanced Wastewater Plant & 0.5 & High, High \\
\hline & & & 591 & 18483 & Howard F Curren Advanced Wastewater Plant & 0.5 & High, High \\
\hline & & 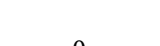 & 592 & 18483 & Howard F Curren Advanced Wastewater Plant & 0.5 & High, High \\
\hline & & 0 & 593 & 18483 & Howard F Curren Advanced Wastewater Plant & 0.5 & High, High \\
\hline & 1 & & 594 & 18483 & Howard F Curren Advanced Wastewater Plant & 0.5 & High, High \\
\hline & & & 778 & 29925 & Neptune Gas Processing Plant & 4.5 & High, High \\
\hline & & & 118 & 3265 & Teche & 23.0 & High, High, High \\
\hline & & 1 & 119 & 3265 & Teche & 348.5 & High, High, High \\
\hline & & & 120 & 3265 & Teche & 42.2 & High, High, High \\
\hline & & & Grar & nd Total & & 607.6 & \\
\hline
\end{tabular}

a. A " 1 " under an SLR scenario indicates that the facility is affected at that level; "0" indicates that the facility is located outside the inundation zone for that scenario. b. Inundation confidence level for the SLR scenario(s) with value " 1 " from left to right.

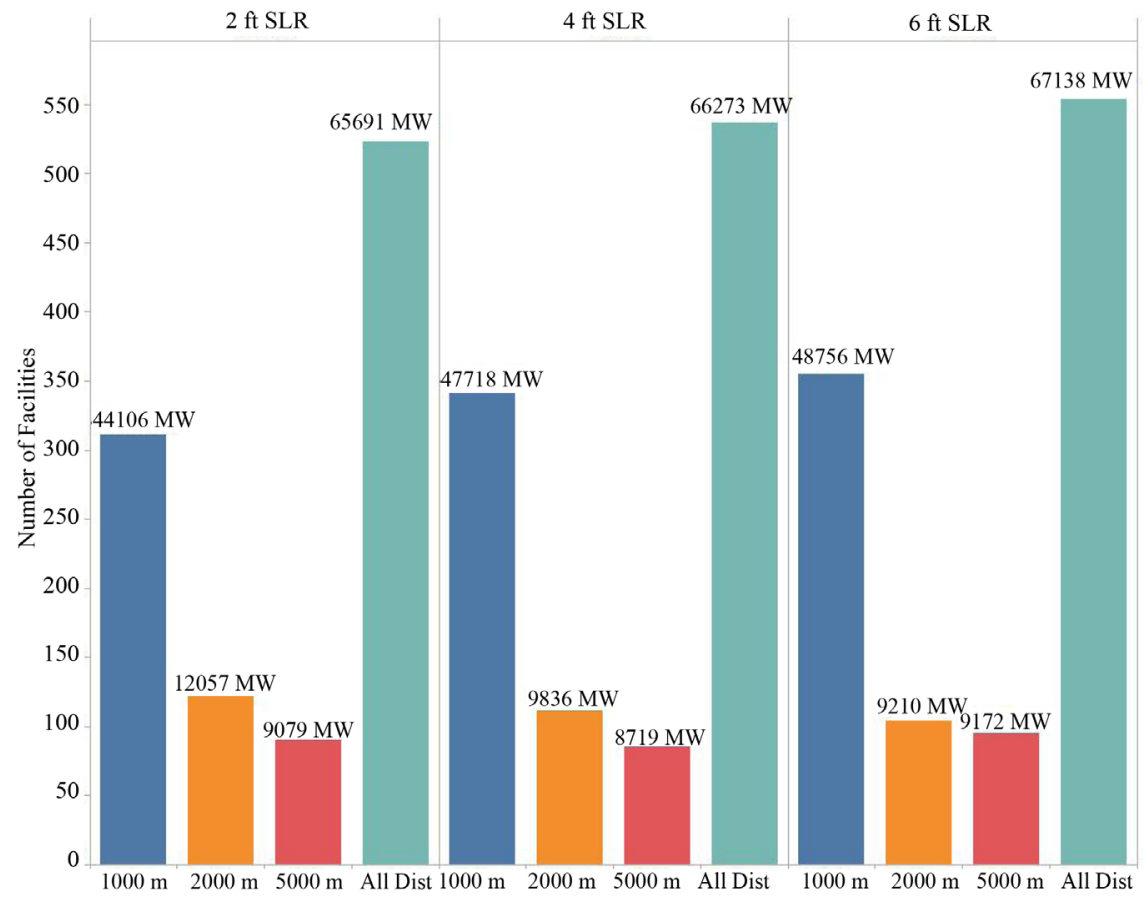

Figure 13. Proximity analysis of power generating facilities along the Gulf Coast at 0.61 $\mathrm{m}(2 \mathrm{ft}), 1.22 \mathrm{~m}(4 \mathrm{ft})$ and $1.83 \mathrm{~m}(6 \mathrm{ft})$ SLR scenarios. 


\subsection{Limitations}

This study is not a comprehensive risk assessment of all energy infrastructures in the region, but only provides a preliminary estimation of existing critical facilities that would be exposed to greater risk as a result of SLR and secondary storm surge or flooding. Important factors not taken into account include the probability of local hurricane strikes at any given location, the depth of inundation, and the degree of damage that would occur to each exposed facility from flooding or storm-related wind damage. This analysis also does not account for methods in which SLR risk could be mitigated, such as the construction of physical barriers, including storm levees, berms, and other barriers, or raising the height of certain facilities or critical equipment located at various infrastructure locations, or other protective facilities [35]. Therefore, the amount of actual risk from SLR may vary significantly among the facilities identified as exposed.

Additionally, this study does not consider the likely reduction of risk because of the relocation of facilities over the next few decades that is within the timeframe of SLR projection scenarios although the likelihood of moving some of these very large facilities is quite low. Another key factor that is increasing storm surge and SLR risk is land subsidence, which, at least according to some estimates, is occurring along the Gulf Coast at rates faster than previously observed. The estimated inundation levels from future SLR scenarios assume that present geomorphological settings will continue. With continued improvement in understanding and predicting these natural processes, better estimates of SLR, and thereby better risk assessments can be made in the future.

\section{Conclusions}

This research assesses the potential and growing risk of SLR on critical energy infrastructure located along the Gulf Coast. Historical tide gauge station data from decadal-scale data suggest that the areas surrounding coastal Louisiana in the Mississippi River Delta plain may have a significantly higher rate of SLR compared to other tide gauges along the Gulf Coast. This is also the area with the highest concentration of energy facilities, not only along the Gulf Coast but across the entire U.S.

Certain types of critical energy infrastructure were found in this research to be particularly vulnerable to a range of SLR scenarios including natural gas processing plants, which, given their relatively close proximity to the coast, are potentially at more risk than refineries and other forms of infrastructure that are often located in marginally more inland locations. Significantly greater numbers of facilities are present within $1000 \mathrm{~m}$ of the future inundation zones under different SLR scenarios indicating their susceptibility to storm surges because of their effects further inland.

This research underscores the likelihood that SLR, if left unaddressed, will likely disrupt critical energy infrastructure and the energy systems to which they are connected. These disruptions will have national and global implications. Fu- 
ture use of expert system-based, integrated, climate-change impact assessment models is warranted to better understand the relationships among industry and environmental variables and ensuing policy implications.

Proactive adaptation practices and improved awareness that identify potential hazards and prepare for future SLR, need to be applied more widely in vulnerable areas. Existing energy infrastructure facilities should consider conducting periodic risk assessments and assessing protective strategies to suit changing environmental conditions in order to maintain the economic value of those initial investments.

\section{Acknowledgements}

The authors would like to thank National Science Foundation (Grant No. 1212112) for their support to this project. The statements, findings, and conclusions are those of the authors and do not necessarily reflect the views of the funding agency.

\section{References}

[1] Dean, R.G. and Houston, J.R. (2013) Recent Sea Level Trends and Accelerations: Comparison of Tide Gauge and Satellite Results. Coastal Engineering, 75, 4-9. http://dcr.rpi.edu/commdesign/class1.html https://doi.org/10.1016/j.coastaleng.2013.01.001

[2] IPCC (2013) Climate Change 2013: The Physical Science Basis. Contribution of Working Group I to the Fifth Assessment Report of the Intergovernmental Panel on Climate Change. Cambridge University Press, Cambridge and New York.

[3] Brown, S., Hanson, S. and Nicholls, R.J. (2014) Implications of Sea-Level Rise and Extreme Events around Europe: A Review of Coastal Energy Infrastructure. Climatic Change, 122, 81-95. https://doi.org/10.1007/s10584-013-0996-9

[4] Schaeffer, R., Szklo, A.S., de Lucena, A.F.P., Borba, B.S.M.C., Nogueira, L.P.P., Fleming, F.P., Troccoli, A., Harrison, M. and Boulahya, M.S. (2012) Energy Sector Vulnerability to Climate Change: A Review. Energy, 38, 1-12. https://doi.org/10.1016/j.energy.2011.11.056

[5] Inyang, H.I. (2009) Impacts of Natural Disasters on Energy Systems. Journal of Energy Engineering, 135, 25-26. https://doi.org/10.1061/(ASCE)0733-9402(2009)135:2(25)

[6] Emanuel, K. (2017) Assessing the Present and Future Probability of Hurricane Harvey's Rainfall. Proceedings of the National Academy of Sciences of the United States of America, 114, 12681-12684. https://doi.org/10.1073/pnas.1716222114

[7] Lee, J.Y. and Ellingwood, B.R. (2017) A Decision Model for Intergenerational Life-Cycle Risk Assessment of Civil Infrastructure Exposed to Hurricanes under Climate Change. Reliability Engineering \& System Safety, 159, 100-107. https://doi.org/10.1016/j.ress.2016.10.022

[8] Olea, R.A. and Coleman, J.L. (2014) A Synoptic Examination of Causes of Land Loss in Southern Louisiana as Related to the Exploitation of Subsurface Geologic Resources. Journal of Coastal Research, 30, 1025-1044. https://doi.org/10.2112/JCOASTRES-D-13-00046.1

[9] Paine, J.G. (1993) Subsidence of the Texas Coast-Inferences from Historical and Late Pleistocene Sea Levels. Tectonophysics, 222, 445-458. 
https://doi.org/10.1016/0040-1951(93)90363-O

[10] Morton, R.A., Bernier, J.C. and Barras, J.A. (2006) Evidence of Regional Subsidence and Associated Interior Wetland Loss Induced by Hydrocarbon Production, Gulf Coast Region, USA. Environmental Geology, 50, 261-274.

https://doi.org/10.1007/s00254-006-0207-3

[11] Ko, J.Y. and Day, J.W. (2004) A Review of Ecological Impacts of Oil and Gas Development on Coastal Ecosystems in the Mississippi Delta. Ocean \& Coastal Management, 47, 597-623. https://doi.org/10.1016/j.ocecoaman.2004.12.004

[12] Akhter, J., Das, L. and Deb, A. (2018) Possible Challenges of Nuclear Power Plants under Climate Change Scenarios. Journal of Climate Change, 4, 63-69. https://doi.org/10.3233/JCC-180007

[13] Anarde, K.A., Kameshwar, S., Irza, J.N., Nittrouer, J.A., Lorenzo-Trueba, J., Padgett, J.E., Sebastian, A. and Bedient, P.B. (2018) Impacts of Hurricane Storm Surge on Infrastructure Vulnerability for an Evolving Coastal Landscape. Natural Hazards Review, 19, Article ID: 04017020. https://doi.org/10.1061/(ASCE)NH.1527-6996.0000265

[14] Cruz, A.M. and Krausmann, E. (2013) Vulnerability of the Oil and Gas Sector to Climate Change and Extreme Weather Events. Climatic Change, 121, 41-53. https://doi.org/10.1007/s10584-013-0891-4

[15] Gil, E.M. and McCalley, J.D. (2011) A US Energy System Model for Disruption Analysis: Evaluating the Effects of 2005 Hurricanes. IEEE Transactions on Power Systems, 26, 1040-1049. https://doi.org/10.1109/TPWRS.2010.2089810

[16] Reed, D.A., Powell, M.D. and Westerman, J.M. (2010) Energy Infrastructure Damage Analysis for Hurricane Rita. Natural Hazards Review, 11, 102-109. https://doi.org/10.1061/(ASCE)NH.1527-6996.0000012

[17] Khakzad, N. and Van Gelder, P. (2018) Vulnerability of Industrial Plants to Flood-Induced Natechs: A Bayesian Network Approach. Reliability Engineering \& System Safety, 169, 403-411. https://doi.org/10.1016/j.ress.2017.09.016

[18] Kaiser, M.J. (2008) The Impact of Extreme Weather on Offshore Production in the Gulf of Mexico. Applied Mathematical Modelling, 32, 1996-2018.

https://doi.org/10.1016/j.apm.2007.06.031

[19] Cruz, A.M., Krausmann, E. and Franchello, G. (2011) Analysis of Tsunami Impact Scenarios at an Oil Refinery. Natural Hazards, 58, 141-162.

https://doi.org/10.1007/s11069-010-9655-x

[20] Church, J.A. and White, N.J. (2011) Sea-Level Rise from the Late 19th to the Early 21st Century. Surveys in Geophysics, 32, 585-602. https://doi.org/10.1007/s10712-011-9119-1

[21] Rahmstorf, S. (2007) A Semi-Empirical Approach to Projecting Future Sea-Level Rise. Science, 315, 368-370. https://doi.org/10.1126/science.1135456

[22] Church, J.A., Monselesan, D., Gregory, J.M. and Marzeion, B. (2013) Evaluating the Ability of Process Based Models to Project Sea-Level Change. Environmental Research Letters, 8, Article ID: 014051. https://doi.org/10.1088/1748-9326/8/1/014051

[23] Parris, A., Bromirski, P., Burkett, V., Cayan, D., Culver, M., Hall, J., Horton, R., Knuuti, K., Moss, R., Obeysekera, J., Sallenger, A. and Weiss, J. (2012) Global Sea Level Rise Scenarios for the US National Climate Assessment. NOAA Tech Memo OAR CPO-1, 37.

[24] Hall, J.A., Gill, S., Obeysekera, J., Sweet, W., Knuuti, K. and Marburger, J. (2016) Regional Sea Level Scenarios for Coastal Risk Management: Managing the Uncertainty of Future Sea Level Change and Extreme Water Levels for Department of Defense Coastal Sites Worldwide. 224 p. 
[25] Sweet, W.V., Kopp, R.E., Weaver, C.P., Obeysekera, J., Horton, R.M., Thieler, E.R. and Zervas, C. (2017) Global and Regional Sea Level Rise Scenarios for the United States.

[26] NOAA Center for Operational Oceanographic Products and Services (2017) Gulf Coast Relative Sea Level Trend.

https://tidesandcurrents.noaa.gov/sltrends/sltrends_us.html

[27] Jankowski, K.L., Tornqvist, T.E. and Fernandes, A.M. (2017) Vulnerability of Louisiana's Coastal Wetlands to Present-Day Rates of Relative Sea-Level Rise. Nature Communications, 8, Article No. 14792.

[28] Van de Lageweg, W.I. and Slangen, A.B.A. (2017) Predicting Dynamic Coastal Delta Change in Response to Sea-Level Rise. Journal of Marine Science and Engineering, 5, 24 .

[29] Dahl, K.A., Fitzpatrick, M.F. and Spanger-Siegfried, E. (2017) Sea Level Rise Drives Increased Tidal Flooding Frequency at Tide Gauges along the US East and Gulf Coasts: Projections for 2030 and 2045. PLOS ONE, 12, e0170949.

[30] Energy Information Administration (2018) Layer Information for Interactive State Maps.

[31] NOAA Office of Coastal Management (2017) Sea Level Rise Inundation. https://coast.noaa.gov/digitalcoast/data/slr.html

[32] Atkinson, J., Smith, J.M. and Bender, C. (2013) Sea-Level Rise Effects on Storm Surge and near Shore Waves on the Texas Coast: Influence of Landscape and Storm Characteristics. Journal of Waterway Port Coastal and Ocean Engineering, 139, 98-117. https://doi.org/10.1061/(ASCE)WW.1943-5460.0000187

[33] Wilby, R.L., Nicholls, R.J., Warren, R., Wheater, H.S., Clarke, D. and Dawson, R.J. (2011) Keeping Nuclear and Other Coastal Sites Safe from Climate Change. Proceedings of the Institution of Civil Engineers-Civil Engineering, 164, 129-136. https://doi.org/10.1680/cien.2011.164.3.129

[34] Zimmerman, R. and Faris, C. (2010) Chapter 4: Infrastructure Impacts and Adaptation Challenges. Annals of the New York Academy of Sciences, 1196, 63-86. https://doi.org/10.1111/j.1749-6632.2009.05318.x

[35] Harris, S.P. and Wilson, D.O. (2008) Mitigating Hurricane Storm Surge Perils at the DeLisle Plant. Process Safety Progress, 27, 177-184.

https://doi.org/10.1002/prs.10226 